認定医ケースプレゼンテーション抄録

純チタン製上部構造を用いたインプラント補綴

黒岩 昭弘

\title{
Super Structure for Implant Made by Cp Titanium
}

Kuroiwa Akihiro

\section{I. 症例の概要}

インプラント補綴の良好な予後を考えるにあたつ て, 上部構造の電気化学的安定は大きな問題点であ り，理想的にはフィクスチャーと同様の素材である純 チタンを上部構造に用いることが望ましい. 本症例は 上部構造のメタルフレームをチタン, 前装には八イブ リッドセラミックスを用いて, 生体安全性の高い補経 を行うことを試みた。

\section{II. 診断と治療方針}

年齢 18 歳女性. 平成 8 年 10 月, 上顎右側中切歯の 外傷による欠損にて来院（図 1). 隣在歯には叢生が あり，修復処置も多いので，まず矯正治療を行い，支 台歯の環境を整えてから，ブリッジによる補経を勧め るも快諾を得ず，インプラントによる補綴を希望し た. 研究模型上で診断用 Waxing を行い, Surgical stent を装着して撮影したパノラマ写真（図 2) で検 討したところ, 埋入部位には十分な距離があるため埋 入可とした.

\section{III. 治療内容}

平成 8 年 12 月, ステントを参考に正確にドリリン グを行い,フィクスチャー (IMZ twin plus：1本) を埋入, 平成 9 年 4 月に二次手術を行った。インプレ

松本歯科大学歯科補経学第 1 講座

Department of Removable Prosthodontics, Matsumoto Dental University, School of Dentistry

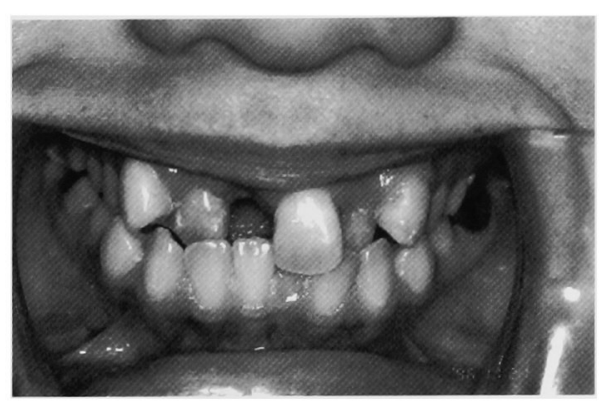

図 1 Intra oral view at the first examination 初診時口腔内

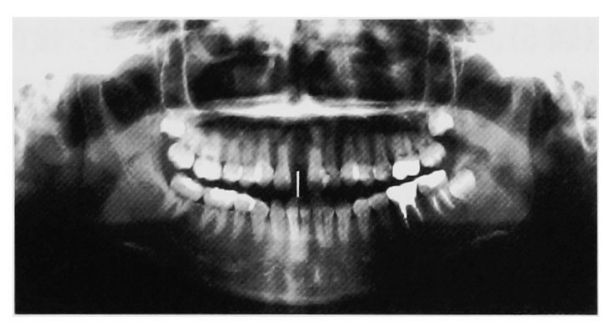

図 2 Orthopantomography パノラマ X 線写真

ションコーピングにスリーブを装着し，オープント レー法で印象採得を行った。同年 6 月に最終補綴物と 同一形態の常温重合レジンによるプロビショナルレス トレーションにて, エマージェンスプロファイルを確 認し, 同年 8 月に上部構造を装着した（図 3). 上部 構造はメタルコーピングを純チタンで鋳造し，前装に はエステニアを用い, ホリゾンタルスクリューにて固 定した。

\section{IV. 経過観察と考察}

経過観察は $1,3,6$ 力月, 1, 1.5 年 (図 4), 2, 


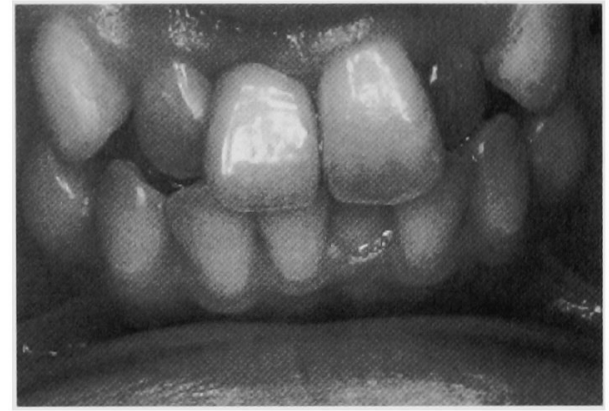

図 3 Intra oral view after treatment 術後写真

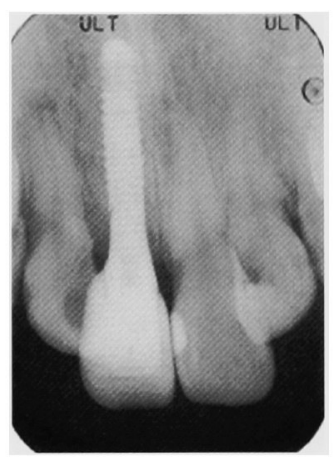

図 4 Radiograph at one year and five months later 1 年 5 力月後の $\mathrm{X}$ 線写真

\section{7 年 (図 5), 3 年後に行った.}

当初は, 患者が 18 歳と比較的若かったことや隣在 歯の齲蝕の罹患状態から，インプラント補経の適応は 考えなかったが，患者の強い希望により埋入すること となった．年齢的に本補綴装置の長期的な予後の安定 が望まれたため，メタルには純チタンを用い，前装は 修繥が容易なハイブリットセラミックスとした。

3 年経過後,インプラント補綴部は炎症も認められ ず，良好な経過が得られた（図 6)。同部位における 補経は成功をおさめたが，患者の年齢から数年単位の 経過ではなく, 10 年以上の長期的な経過観察を行い, メインテナンスや指導を行う必要がある. 現時点で は，患者が本学病院から離れたところへ転居したた

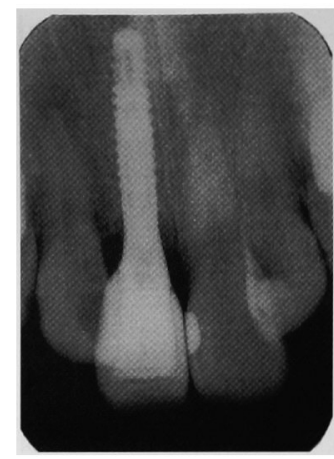

図 5 Radiograph at two years and seven months later 2 年 7 力月後の $\mathrm{X}$ 線写真

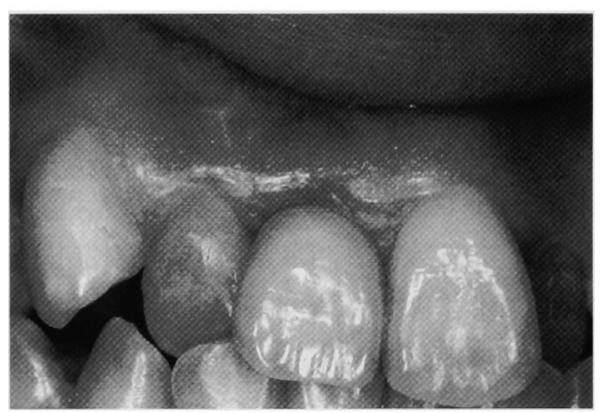

図 6 Three years after treatment 術後 3 年

め, 半年に一度のリコールを行っている.

インプラントのフィクスチャーの材質は，ほとんど のものがチタンである. 上部構造がチタンであれば, 電気化学的にも安定した補綴物となる. 構造力学的に は従来から白金加金でフレームを製作していたので, 強度的に問題はないと考える1 3).

\section{文献}

1）黒岩昭弘, 五十嵐順正. ここまできたチタン鋳造. QDT 21： 40-55, 1996.

2）黒岩昭弘. スプルーの条件がチタン鋳造の鋳込率に及ほすす影 響. 歯材器 $11: 262-277,1992$.

3）黒岩昭弘, 五十嵐順正. 金属床義歯へのチタンの応用. 補綴誌 42: 547-558, 1998. 